\title{
COMPARISONS BETWEEN TWO ECONOMICALLY VALUABLE FOREST SPECIES (Eucalyptus grandis AND Pinus taeda) IN RELATION TO SEED BEHAVIOUR UNDER CONTROLLED DETERIORATION ${ }^{1}$
}

\author{
Jussara Bertho Fantinatti² e Roberto Usberti ${ }^{3}$
}

\begin{abstract}
The objectives of this work were to analyze seed behaviour under controlled deterioration and estimate viability equations for forest species Eucalyptus grandis and Pinus taeda. Desired moisture content levels were achieved from initial values after either rehydration over water or drying over silica gel, both at $25^{\circ} \mathrm{C}$. Seed sub samples with 8 moisture contents each for $E$. grandis (1.2 to $18.1 \%$, initial value of $11.3 \%$ ) and P. taeda (1.5 to $19.5 \%$, initial value of $12.9 \%$ ) were sealed in laminate aluminium-foil packets and stored in incubators maintained at 40,50 and $65{ }^{\circ} \mathrm{C}$. The seeds from these species exhibited true orthodox and sub-orthodox storage behaviour, respectively, however E. grandis showed higher seed storability, probably due to a different seed chemical composition. Lowest moisture content limits estimated for application of the viability equations at $65{ }^{\circ} \mathrm{C}$ were 4.9 and $4.1 \mathrm{mc}$ for $E$. grandis and P. taeda, on equilibrium with $\pm 20 \%$ $\mathrm{RH}$. The viability equation estimated quantified the response of seed longevity to storage environment well with $K_{E}=9.661$ and 8.838; $C_{W}=6.467$ and 5.981; $C_{H}=0.03498$ and $0.10340 ; C_{Q}=0.0002330$ and 0.0005476 , for E. grandis and P. taeda, respectively. .
\end{abstract}

Keywords: Forest species, Seed storability and Viability equation.

\section{COMPARAÇÕES ENTRE DUAS ESPÉCIES FLORESTAIS DE VALOR ECONÔMICO (Eucalyptus grandis AND Pinus taeda) COM RELAÇÃO AO COMPORTAMENTO DAS SEMENTES SOB DETERIORAÇÃO CONTROLADA}

\begin{abstract}
RESUMO - Os objetivos deste trabalho foram analisar o comportamento de sementes sob deterioração controlada e estimar as equações de viabilidade das espécies florestais Eucalyptus grandis e Pinus taeda. Os graus de umidade desejados foram obtidos a partir dos valores iniciais após a reidratação sobre água ou secagem sobre sílica-gel, ambos a $25{ }^{\circ} \mathrm{C}$. Subamostras de sementes com 8 C graus de umidade cada de E. grandis (1,2 a 18,1\%, valor inicial de 11,3\%) e de P. taeda (1,5 a 19,5\%, valor inicial de 12,9\%) foram colocadas em envelopes laminados de alumínio e mantidas em incubadoras a 40, 50 e $65{ }^{\circ} \mathrm{C}$. O comportamento das espécies durante o armazenamento foi ortodoxo e subortodoxo, respectivamente. Entretanto, o potencial de armazenamento de sementes de E. grandis foi maior, talvez devido à diferente composição química das sementes. Os limites inferiores de graus de umidade para aplicação da equação de viabilidade a $65{ }^{\circ} \mathrm{C}$ foram 4,9 e 4,1\% em E. grandis e P. taeda, em equilíbrio com $\pm 20 \%$ UR. As equações de viabilidade estimadas quantificam bem a resposta da longevidade das sementes ao ambiente de armazenamento, como se segue: $K_{E}=9,661$ e 8,838; $C_{W}=6,467$ e 5,981; $C_{H}=0,03498$ e 0,10340; $C_{Q}=0,0002330$ e 0,0005476, em E. grandis e P. taeda, respectivamente.

Palavras-chave: Espécies florestais, Armazenabilidade de sementes e Equação de viabilidade.
\end{abstract}

\footnotetext{
${ }^{1}$ Recebido em 03.02.2009 e aceito para publicação em 25.08.2010.

${ }^{2}$ Faculty of Agricultural Engineering, UNICAMP, Campinas, Brazil. E-mail: <jussara.fantinatti@gmail.com>.

${ }^{3}$ Plant Protection Agency, Sao Paulo State, Campinas, Brazil. E-mail: <usberti@cati.sp.gov.br>.
} 


\section{INTRODUCTION}

Eucalyptus spp. and Pinus spp. are the main sources for supplying raw material for the production of short and long fiber cellulose and mechanical processing and have been established around 3,800,000 ha of brazilian reforested areas.

Seed storability is affected mainly by moisture content (mc) and storage temperature (T). According to Harrington (1963), mc is the most important factor in seed longevity and the viability period could be doubled after reductions of either $1 \%$ in $\mathrm{mc}$ or $5.6^{\circ} \mathrm{C}$ in $\mathrm{T}$.

Roberts (1973) classified the seeds in storage as orthodox, showing a medium life around 3-15 years, with seed longevity inversely proportional to $\mathrm{T}$ and mc whereas recalcitrant seeds have short viability and more difficult conservation. The orthodox seed behavior can be investigated thereby reducing both moisture content and temperature, and their longevity can be described in a quantifiable and predictable way

Bonner (1990) proposed a specific classification for forest species: true orthodox, which tolerates desiccation at low $\mathrm{T}$ and maintains seed viability for long periods in dry conditions (Eucalyptus, Pinus and Acacia); sub-orthodox, which could be stored in the same conditions above for the maximum of 6 years, presenting high lipid content, small size and fine seed coats; recalcitrant temperate, which are sensitive to desiccation but could be stored at $\mathrm{T}$ around freezing (Quercus spp.) and recalcitrant tropical, presenting big seeds and being sensitive to desiccation and freezing (coconut, cocoa and mango).

Several equations have been proposed to relate storage conditions with seed viability, aiming at predicting seed survival as well as seed sensibility to mc and T. The viability equation presented by Ellis and Roberts (1980) $\left(\mathrm{v}=K_{i} \mathrm{p} / 10_{E}^{K}{ }_{W}^{C} \log C_{H} C_{Q} C_{Q}^{\mathrm{t}^{2}}\right)$ allows estimates of any seed lot viability during storage at different $\mathrm{T}$ and mc and includes five constants, as follows: one quantifying the initial seed lot quality $\left(K_{i}\right)$, one for each species $\left(K_{E}\right)$, one indicating the logarithmic response of seed longevity to mc $\left(C_{W}\right)$ and two constants for linear and quadratic $\mathrm{T}\left(C_{H}\right.$ and $C_{Q}$, respectively).

The main objectives of this work were (1) analyzing E. grandis W.Hill ex Maiden and P. taeda L. seed behavior under controlled deterioration and (2) estimating viability equations.

Revista Árvore, Viçosa-MG, v.35, n.1, p.77-84, 2011

\section{MATERIALAND METHODS}

This research work was carried out at the Laboratory of Post-harvest Technology, Faculty of Agricultural Engineering, Campinas State University, Brazil, from 2000 to 2003. E. grandis and P. taeda seed lots were harvested in 1999/2000 and 2000/2001 seasons, in Forest Experimental Stations of Anhembi and Itapetininga, Sao Paulo State, respectively.

E. grandis physical purity analysis was performed using a 5-g-working sample, which was separated in pure seeds, other seeds and inert matter. The 1,000seed weight determination for both species was carried out using eight 100-pure seed sub samples (ISTA, 2006).

Lipid content was detected in 2-g-ground seed samples, placed in Whatman paper cartridges $(80 \mathrm{~mm}$ length $\mathrm{x} 33 \mathrm{~mm}$ of internal diameter); the extraction was performed with ether of petroleum in a Soxhlet apparatus for $5 \mathrm{~h}$ and the amount of lipids was determined gravimetrically (AOAC, 1995). Activity of water was carried out at $25 \pm 0.3^{\circ} \mathrm{C}$ on three replicates of ground seeds for each mc, using the chilled-mirror dew point technique.

Seed mc were adjusted to eight levels from initial values, using desiccators with silica gel or through rehydration over water $(4 \mathrm{~cm})$, both at $25^{\circ} \mathrm{C}$. Seed sub samples were weighed periodically for controlling the amount of removed or absorbed water, until desired mc had been achieved. After a 4 day-period for stabilization at $4^{\circ} \mathrm{C}$ in sealed containers, seed mc (\%, f.wt.) was determined at $130-133^{\circ} \mathrm{C}$ during 2 hours for each mc (ISTA, 2006), using three $5 \mathrm{~g}$ sub samples of intact (E. grandis) and ground seeds (P. taeda) and the values recorded are listed in Table 1.

Table 1 = Seed moisture content analyzed for the species. Tabela 1- Graus de umidade de sementes analisados para as espécies.

\begin{tabular}{cc}
\hline E. grandis & $P$. taeda \\
\hline 1.2 & 1.5 \\
3.0 & 4.0 \\
4.7 & 5.7 \\
7.5 & 8.0 \\
$11.3 *$ & $12.9 *$ \\
14.4 & 13.5 \\
16.3 & 17.0 \\
18.1 & 19.5 \\
\hline
\end{tabular}

* Initial mc values Graus de umidade iniciais. 
Seeds were sealed in laminated paper (polyester / aluminium / low density polyethylene, with total thickness of $65 \mu \mathrm{m}$ ) with a minimum of $10 \times 0.6 \mathrm{~g}$ sub samples for E. grandis and 10 x 200 seed sub samples for P. taeda for each combination $\mathrm{mc} / \mathrm{T}$ and stored at 40,50 and $65\left( \pm 0.5^{\circ} \mathrm{C}\right)$, until complete survival curves were achieved (Table 2).

E. grandis seed germination tests were performed using 4 x 0.15 g sub samples; for $P$. taeda, a previous dormancy releasing through stratification was proceeded ( $5^{\circ} \mathrm{C}, 28$ days), using 8 x 25 seed sub samples. Seed sub samples were placed over a moistened filter paper in $11 \mathrm{x} 11 \mathrm{~cm}$ plastic boxes and kept in an incubator under alternate temperature regime $\left(20-30^{\circ} \mathrm{C}, 16-8\right.$ hours, $40 \mathrm{~W}$ white light at $30^{\circ} \mathrm{C}$ ); seedling counts were recorded at 7 and 14 days (E. grandis) and at 7 and the final one at 28 days (P. taeda). Seeds were considered germinated according to the criterion of the radicle protrusion (SOUZA and CARDOSO, 2000).

Seeds with mc below $6 \%$ were previously rehydrated at $25^{\circ} \mathrm{C}$ during 48 hours over a nylon screen in a plastic box with $1.5 \mathrm{~cm}$ of distilled water on the bottom, aiming at avoiding predictable damages due to fast rehydration.

The origin of the survival curves on the Y-axis doesn't converge to the same point, requiring a statistical adjustment in order to get the same value $\left(K_{i}\right)$ with the smallest possible deviation. The germination percentage values were plotted in $\mathrm{X}-\mathrm{Y}$ graphs and regression lines were fitted to probit values through Y-axis scale transformation. The residual deviances for survival curves at different $\mathrm{T}$ were analyzed to give

Table 2 - E. grandis and $\boldsymbol{P}$. taeda seed mc analyzed during storage at 40,50 and $65^{\circ} \mathrm{C}$.

Tabela 2 - Graus de umidade de sementes de E. grandis $e$ $P$. taeda analisados durante o armazenamento a 40,50 e $65^{\circ} \mathrm{C}$.

Storage temperature $\left({ }^{\circ} \mathrm{C}\right)$

Temperatura de armazenamento $\left({ }^{\circ} \mathrm{C}\right)$

\begin{tabular}{cccccc}
\hline \multicolumn{3}{c}{ E. grandis } & \multicolumn{3}{c}{ P. taeda } \\
\hline 40 & 50 & 65 & 40 & 50 & 65 \\
& 1.2 & 1.2 & 1.5 & 1.5 & 1.5 \\
& 3.0 & 3.0 & 4.0 & 4.0 & 4.0 \\
& 4.7 & 4.7 & 5.7 & 5.7 & 5.7 \\
7.5 & 7.5 & 7.5 & 8.0 & 8.0 & 8.0 \\
11.3 & 11.3 & 11.3 & 12.9 & 12.9 & 12.9 \\
14.4 & 14.4 & 14.4 & 13.5 & 13.5 & 13.5 \\
16.3 & 16.3 & 16.3 & 17.0 & 17.0 & \\
18.1 & 18.1 & 18.1 & 19.5 & & \\
\hline & & & &
\end{tabular}

the best fit to the viability equation, using the multiple regression analysis within the generalized linear model (HAY et al., 2003).

The specific constants of each species were achieved using decimal logarithms of sigma (frequency of seed deaths distribution in time or the number of days required for seed germination drop by one probit) and mc for each combination $\mathrm{mc} / \mathrm{T}$. Seed germination with or without rehydration was analyzed through a randomized statistical design.

\section{RESULTS AND DISCUSSION}

Seed physical pure percentages and 1,000-seed weights detected were $19.0 \%$ and $0.226 \mathrm{~g}$ (E.grandis) and $100.0 \%$ and $25.0 \mathrm{~g}$ (P. taeda). Extraction relationship or fruit / seed relationship is the amount of capsules required to produce one $\mathrm{kg}$ of mixed seeds and presented a medium rate of 15:1 for E. grandis. Taking into account those values, the numbers of pure seeds / kg were estimated in 841,643 and 40,000 for E. grandis and $P$. taeda, respectively, which is similar to the result reported by Vieira and Diniz, 1995 ( \pm 700,000 / kg, E. grandis). According to Gentil and Ferreira (2002), the 1,000-seed weight is affected by seed size uniformity, foundation plants and environmental factors.

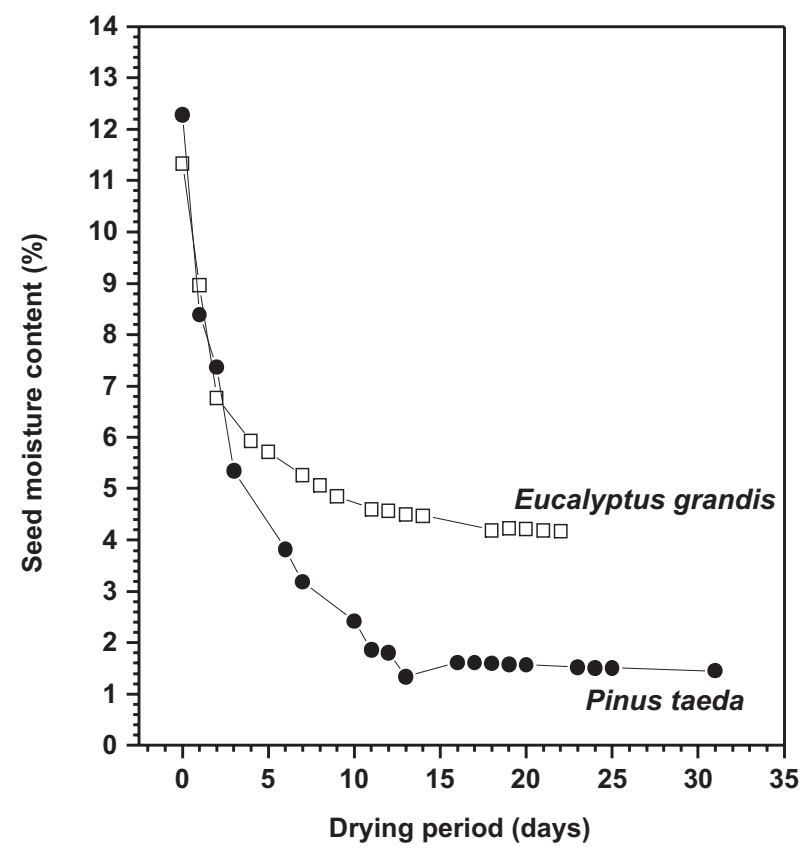

Figure 1 - Seed drying rates over silica gel at $25^{\circ} \mathrm{C}$ for $E$. grandis and $P$. taeda.

Figura 1 - Taxas de secagem de sementes sobre sílica gel a $25{ }^{\circ} \mathrm{C}$ de E. grandis e P. taeda.

Revista Árvore, Viçosa-MG, v.35, n.1, p.77-84, 2011 
Seed lipid contents recorded in E. grandis and P. taeda were 24.2 and $52.3 \%$, which were higher than those achieved for Dalbergia nigra and Dimorphandra mollis (7.0\% and 14\%), respectively (CHAVES and USBERTI, 2004)

E. grandis seeds lost water faster over silica gel after 48-h-drying, E. grandis and P. taeda presented seed mc around 6.8 and $7.4 \%$ (Figure 1), probably due to the different lipid contents (BROOKER et al., 1992). Seed $\mathrm{mc}$ for both species presented an inverse relationship with drying period. The drying process over silica gel revealed positive results for the species and the lowest mc were obtained without damages to the seeds.

No statistical differences were recorded for E. grandis seed germination among mc (Table 3); however the highest and lowest percentages were obtained with $7.5 / 11.3 \% \mathrm{mc}$ (no rehydration) and with $1.2 \% \mathrm{mc}$ (with rehydration), emphasizing the need for rehydration before germination test for mc lower than $6 \%$. Lowest $P$. taeda seed germination percentages were recorded with 8.0 and $1.5 \% \mathrm{mc}$, unrelated to rehydration however seeds with $12.9 \%$ mc presented a significant increase in germination after rehydration. Bradford (1995) reported that seed germination normally increases after rehydration.

Table 3 - Seed germination (\%) of E. grandis and P. taeda after drying over silica gel.

Tabela 3 - Germinação de sementes (\%) de E. grandis e P. taeda após a secagem sobre sílica-gel.

\begin{tabular}{ccc}
\hline Seed mc & \multicolumn{2}{c}{ E. grandis } \\
\cline { 2 - 3 } & $\begin{array}{c}\text { No rehydration } \\
\text { Sem reidratação }\end{array}$ & $\begin{array}{c}\text { With rehydration } \\
\text { Com reidratação }\end{array}$ \\
\hline 11.3 & 87.5 a & 82.5 a \\
7.5 & 84.5 a & 70.5 a \\
4.7 & 78.0 a & 79.0 a \\
3.0 & 68.0 a & 80.0 a \\
1.2 & 68.0 a & 77.0 a \\
\hline & & 95.0 a A \\
\hline 12.9 & 82.0 a B & 78.5 b A \\
8.0 & 75.5 ab A & 85.0 ab A \\
5.7 & 81.0 a A & 89.0 ab A \\
4.0 & 85.0 a A & $74.0 \mathrm{~b} \mathrm{~A}$ \\
1.5 & 63.0 b A & \\
\hline
\end{tabular}

Means followed by different lower case letters in the columns and upper case letter in the lines, are statistically different at $\mathrm{p}<0,05$.

Médias seguidas por diferentes letras minúsculas nas colunas e maiúsculas nas linhas são estatisticamente diferentes a $p<0,05$.

Revista Árvore, Viçosa-MG, v.35, n.1, p.77-84, 2011
Seeds of $P$. taeda presented a lower equilibrium relative humidity (erh) than E. grandis, when stored in similar conditions. Oily seeds present erh lower than starchy ones, when exposed to similar environments, since they don't absorb or absorb less water, due to being hydrophobic.

Seed longevity increased logarithmically according to reduction of mc until all weak bound water had been removed. The inflection points of the desorption isotherms for E. grandis and P. taeda (4.9\% mc, erh at $22.9 \%$ and $4.1 \% \mathrm{mc}$, erh at $21.2 \%$, Figure 2 ) mean the discontinuity of the inverse relationship between longevity and mc or the lowest mc limits for application of the viability

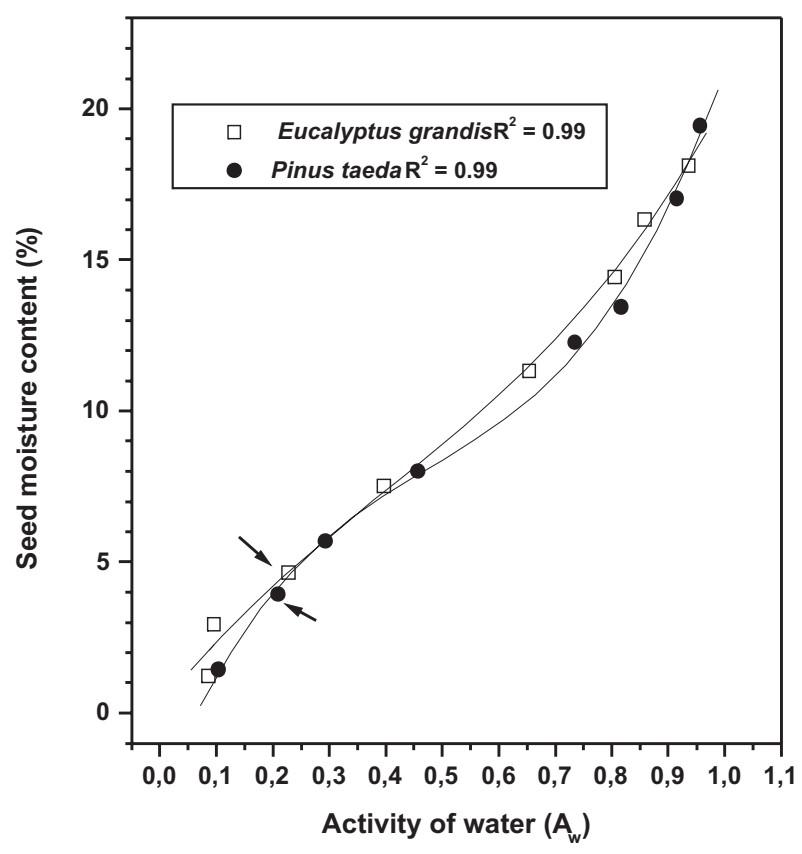

Figure 2-Relationship between seed mc (\%, f.wt.) and activity of water (\%) of $E$. grandis and $P$. taeda, at 25 C. The curves represent sorption and desorption isotherms, above and below the initial mc values (11.3 and $12.9 \%$, respectively). The arrows point out the inflection points of the isotherms (4.9 and $4.1 \% \mathrm{mc}$ ), which mean the lowest mc limit for application of the viability equations at $65 \mathrm{C}$.

Figura 2 - Relações entre grau de umidade (\%, b.u.) e atividade de água (\%) de E. grandis e P. taeda a $25^{\circ} \mathrm{C}$. As curvas representam isotermas de sorção e desorção, acima e abaixo dos valores inicias de graus de umidade (11,3 e 12,9\%, respectivamente). As setas apontam para os pontos de inflexão das isotermas (graus de umidade de 4,9 e 4,1\%), que indicam os limites inferiores de grau de umidade para a aplicação da equação de viabilidade a $65{ }^{\circ} \mathrm{C}$. 
equation at $65^{\circ} \mathrm{C}$. Those values have already been estimated for another species with variable results, as follows: $2.4 \% \mathrm{mc}$ for peanuts (USBERTI and GOMES, 1998); 6.2\% mc for peas (ELLIS et al., 1989); 2.9 and $4.0 \%$ mc for D. nigra and D. mollis (CHAVES and USBERTI, 2004) and 3.6\% mc for cottonseed (USBERTI et al., 2006).
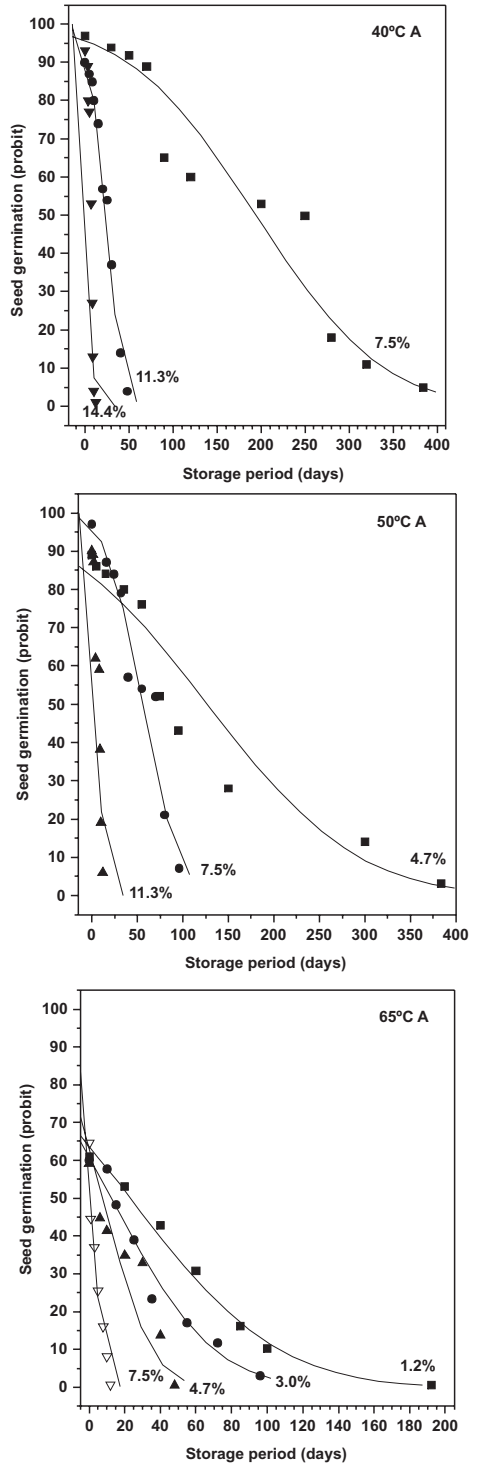

Probit seed survival curves for the species after storage at 40,50 and $65^{\circ} \mathrm{C}$ are displayed in Figure 3, showing the effects of mc and $\mathrm{T}$ on seed storability. When mc and $\mathrm{T}$ were reduced, predictable seed longevity increases were observed. Ellis (1984) reported that seed survival curves always present the same format, differing among them just in relation to the deterioration period,
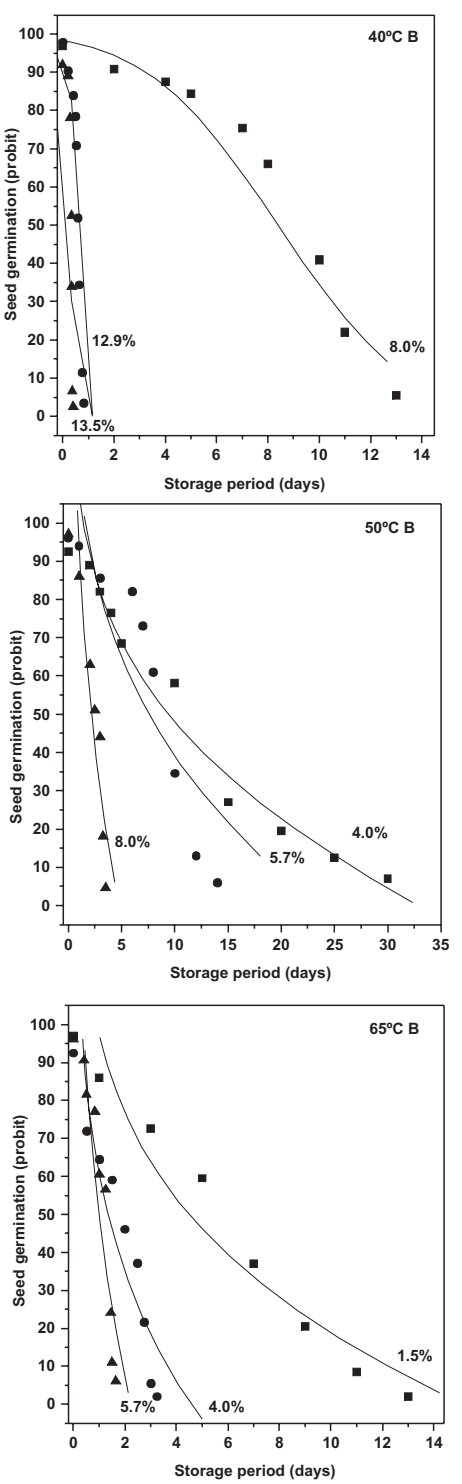

Figure 3 - Seed survival curves (probit) for E. grandis (A, on the left) and P. taeda (B, on the right), stored at 40, 50 and $65^{\circ} \mathrm{C}$. Symbols and straight lines mean germination percentages and survival curves, respectively.

Figura 3 - Curvas de sobrevivência de sementes (em probitProbit) para de E. grandis (A, à esquerda) e P. taeda (B, à direita), após o armazenamento a 40,50 e $65^{\circ} \mathrm{C}$. Símbolos e retas significam porcentagens médias de germinação e curvas de sobrevivência, respectivamente. 
but presenting the same standard deviation. In the present study the sigmoid shape of the survival curves was strongly affected by temperature and mc increase especially for $P$. taeda seeds.

Relationship differences between mc and longevity were observed and $P$. taeda seed sensitivity to mc was higher than E. grandis. Tompsett (1986) worked with two arboreal species and verified that Ulmus carpinifolia Borkh. seed was significantly more sensitive to mc than Terminalia brassii Exell.

Seeds of E. grandis stored at $40^{\circ} \mathrm{C}$ with $7.5 \% \mathrm{mc}$ had a sigma of 90 days, while for $P$. taeda with $8.0 \% \mathrm{mc}$ that value was reduced to 5 days (Figure 3 ). The combination of highest $\mathrm{T}$ and $\mathrm{mc}$ resulted in seed longevity reductions, confirming the tremendous effect of mc on seed longevity.

E. grandis seeds stored at $50{ }^{\circ} \mathrm{C}$ with $7.5 \% \mathrm{mc}$ presented a sigma of 40 days, while for $P$. taeda with $8.0 \%$ mc that value was reduced to 2 days (Figure 3 ). In seed samples with 4.7 and $4.0 \% \mathrm{mc}$, the calculated sigma values were 55 and 4 days, respectively. Almeida et al., 2005, working with three Pinus species, reported that $P$. taeda seed germination was not affected after a 2-minute-storage at $\mathrm{d}^{\prime} 50^{\circ} \mathrm{C}$.

Seeds of E. grandis stored at 65C with 1.2 and 7.5\% mc presented sigma values of 40 and 1 days, respectively; however in $P$. taeda with $1.5 \% \mathrm{mc}$ that time was 3 days (Figure 3). For seed germination to reach values lower than 5\%, with 3.0 and $4.0 \%$ mc, 96 and 3.25 days were required, respectively. $P$. taeda seed germination reduction was higher than for E. grandis throughout the experiment, since oily seeds deteriorate faster than starchy ones.

Seed mc and sigma values after storage at 40, 50 and $65^{\circ} \mathrm{C}$ are presented in Table 4 . E. grandis seeds with $18.1 \%$ mc stored at 40 and $50^{\circ} \mathrm{C}$ presented sigma values of 0.4 and 0.1 day; in $P$. taeda with $17.0 \% \mathrm{mc}$ stored at 40 and $50^{\circ} \mathrm{C}$, those values decreased to 0.009 and 0.002 day.

Constraining 24 survival curves to the same origin point on the Y-axis yielded different $K i$ values for $E$. grandis and P. taeda (1.351 and 1.819; 90 and 98\% seed germination). Significant effects for log mc and $\mathrm{T}$ were observed while non-significant ones were calculated for the interaction $\log \mathrm{mc} / \mathrm{T}(F=0.47$ P. taeda; 3.08 E. grandis $)$.

Better statistic adjustments to estimate viability constants were achieved after removal of the lowest mc results at 65 and $50^{\circ} \mathrm{C}(1.2,3.0$ and $4.7 \%$ mc for
Table 4 - Seed mc (\%) and sigma (days) for E. grandis and $P$. taeda. stored at 40,50 and $65^{\circ} \mathrm{C}$.

Tabela 4-Graus de umidade (\%) e sigma (dias) de sementes de E. grandis e P. taeda, armazenadas a 40, 50 e $65^{\circ} \mathrm{C}$.

\begin{tabular}{lcccccc}
\hline Mc & \multicolumn{7}{c}{ Sigma (days) } \\
\cline { 2 - 7 } & $40{ }^{\circ} \mathrm{C}$ & $50{ }^{\circ} \mathrm{C}$ & $65{ }^{\circ} \mathrm{C}$ & $40{ }^{\circ} \mathrm{C}$ & $50{ }^{\circ} \mathrm{C}$ & $65{ }^{\circ} \mathrm{C}$ \\
1.2 & - & - & 43.19 & - & - & - \\
1.5 & - & - & - & - & - & 3.29 \\
3.0 & - & - & 27.81 & - & - & - \\
4.0 & - & - & - & - & 7.35 & 0.97 \\
4.7 & - & 97.27 & 14.51 & - & - & - \\
5.7 & - & - & - & - & 4.59 & 0.6 \\
7.5 & 137.6 & 40.83 & 3.59 & - & - & - \\
8.0 & - & - & - & 4.7 & 1.27 & 0.15 \\
11.3 & 17.33 & 4.97 & 0.44 & - & - & - \\
12.9 & - & - & - & 0.3 & 0.06 & 0.006 \\
13.5 & - & - & - & 0.15 & 0.023 & 0.005 \\
14.4 & 4.2 & 0.84 & 0.13 & - & - & - \\
16.3 & 0.76 & 0.29 & 0.03 & - & - & - \\
17.0 & - & - & - & 0.009 & 0.002 & - \\
18.1 & 0.4 & 0.1 & - & - & - & - \\
19.5 & - & - & - & 0.001 & - & - \\
\hline
\end{tabular}

E. grandis; 1.5 and $4.0 \%$ mc for $P$. taeda). The constants $K\left(K=K_{E}-C_{H} \mathrm{t}-C_{Q} \mathrm{t}^{2}\right)$ obtained define the equations at 40,50 and $65^{\circ} \mathrm{C}$, as follows: E. grandis: $K=8.084 ; 5.745 ; 2.486$ and $C_{W}=6.641 ; 5.103 ; 2.777$; P. taeda: $K=8.802 ; 4.673 ; 1.454$ and $C_{W}=8.748$; 5.596; 2.949 .

The constants $K_{E}$ and $C_{W}$ estimated for $E$. grandis (9.661 and 6.467) were different from those calculated for P. taeda (8.838 and 5.981), confirming the observation done by Ellis (1984) that for cereal seeds those values are higher than oily seeds, indicating the need for drying those seeds to lower mc levels. The constants that reflect seed sensitivity to $\mathrm{T}\left(C_{H}\right.$ and $\left.C_{Q}\right)$ were 0.03498 and 0.0002330 (E. grandis) and 0.10340 and 0.0005476 (P. taeda).

The viability equation constants for E. grandis appear to be close to that reported for cottonseed $\left(K_{E}=9.240, C_{W}=5.190, C_{H}=0.03965\right.$ and $\left.C_{Q}=0.000426\right)$ (USBERTI et al., 2006). An inverse relationship was observed between mc and seed longevity for both species.

The viability equations estimated for E. grandis and $P$. taeda seeds were:

$$
\begin{aligned}
& \mathrm{v}=K i-\mathrm{p} / 10^{9.661-6.467 . \operatorname{logm}-0.03498 \mathrm{t}-0.0002330 \mathrm{t} 2} \text { E. grandis } \\
& \mathrm{v}=K i-\mathrm{p} / 10^{8.838-5.981 . \operatorname{logm}-0.10340 \mathrm{t}-0.0005476 \mathrm{t} 2} \quad P . \text { taeda }
\end{aligned}
$$



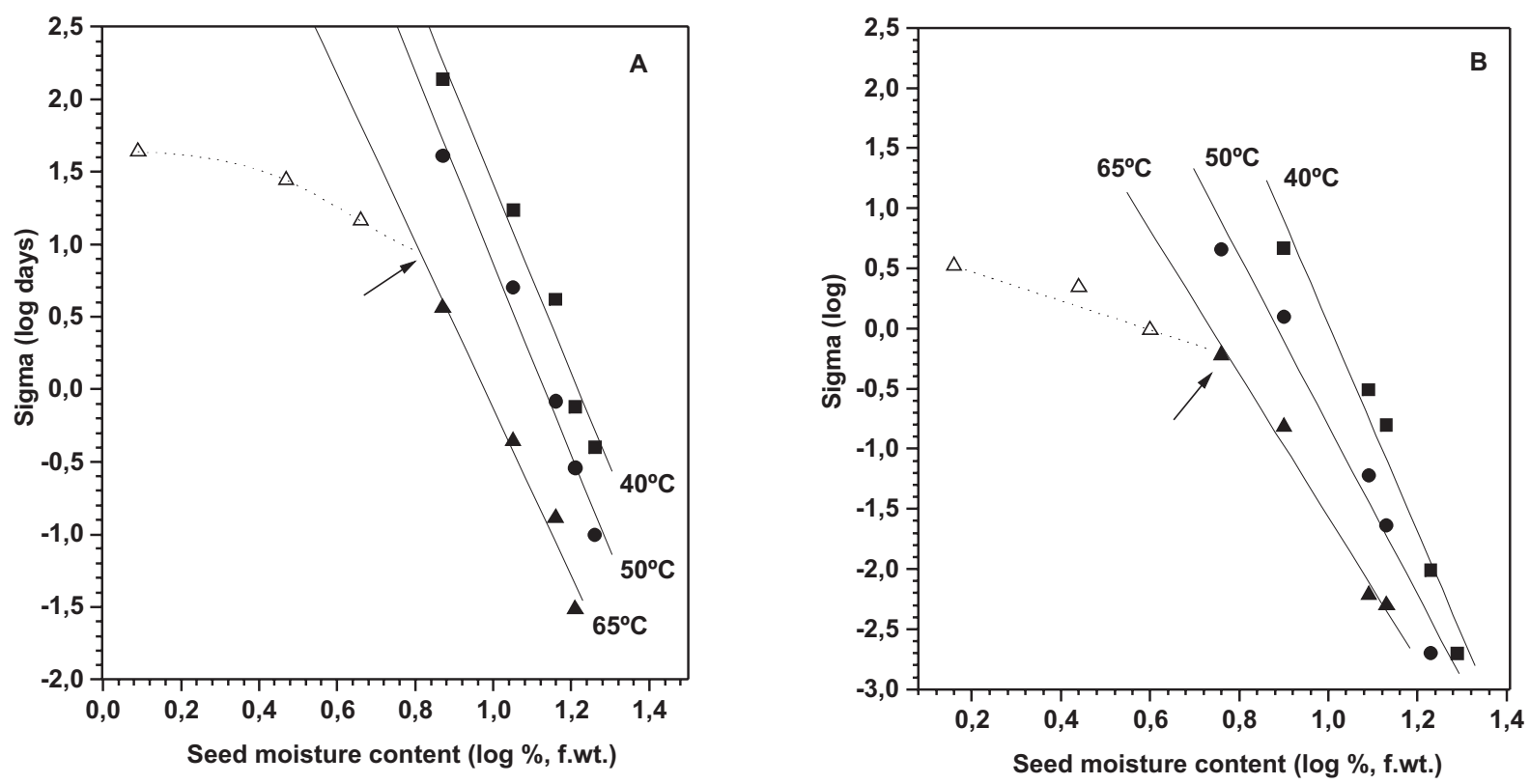

Figure 4 - Relationship between the logarithm of seed mc and the logarithm of sigma for E. grandis (A, on the left) and P. taeda (B, on the right), stored at 40,50 and $65^{\circ} \mathrm{C}$. Solid lines represent slopes, which are constrained to one common value. The dotted lines show different trends at $65^{\circ} \mathrm{C}$, below the lower mc limit for application of the viability equation, pointed out by the arrows.

Figura 4-Relações entre o logaritmo de grau de umidade da semente e o logaritmo de sigma para de E. grandis (A, à esquerda) e P. taeda (B, à direita), após o armazenamento a 40, 50 e $65^{\circ} \mathrm{C}$. Linhas sólidas representam curvas, após serem direcionadas a um ponto comum. As linhas pontilhas mostram diferentes tendências a $65^{\circ} \mathrm{C}$, abaixo do limite inferior de grau de umidade para a aplicação da equação de viabilidade, indicados indicado pelas setas.

Figure 4 shows the logarithmic relationship between seed mc and sigma at 40,50 and $65^{\circ} \mathrm{C}$ and reveals the parallelism among the straight lines, due to different T used. Dickie et al. (1990) reported that the viability equation could be applied from -13 to $90^{\circ} \mathrm{C}$ and also observed a negative relationship between $C_{W}$ values and seed oil content, among different species.

Medeiros et al. (1998), using $K_{E}=7.5498$ and $C_{W}=3.76$ and adopting $C_{H}=0.0329$ and $C_{Q}=0.000478$ as universal constants, estimated the sigma value of 1,167 years for the species Astronium urundeuva (Fr.All.) Engl. stored at $-20^{\circ} \mathrm{C}$ with $\mathrm{mc}$ in equilibrium at $15^{\circ} \mathrm{C}$ and $15 \% \mathrm{RH}$.

Using the viability equations and adopting $4^{\circ} \mathrm{C}$ (domestic refrigerator) and 7.5 and $8.0 \%$ mc (erh at 40 and $45 \%$ ), achieved in a 2-day drying period over silica gel, it is expected that E. grandis and $P$. taeda seeds would present sigma values of 19.9 and 2.9 years. That different performance could be due to the different chemical composition of those seeds, since $P$. taeda presented higher lipid content.

\section{CONCLUSIONS}

. P. taeda and E. grandis presented, respectively, sub- and true orthodox seed behaviour to storage.

. P. taeda revealed erh and seed storability lower than E. grandis.

. Lowest limits for application of the viability equation at $65^{\circ} \mathrm{C}$ were 4.9 and $4.1 \% \mathrm{mc}$ for $E$. grandis and $P$. taeda, respectively.

\section{ACKNOWLEDGEMENTS}

To FAPESP (Brazilian Research Agency) for the doctorate scholarship to the first author.

\section{REFERENCES}

ALMEIDA, F.A.C. et al. Efeito da temperatura sobre a germinação de três espécies de Pinus cultivadas no Brasil. (Effect of temperature on germination of three Pinus species cultivated in Brazil). Brazilian Journal of Forest Science, v.29, n.5, p.757-765, 2005.

Revista Árvore, Viçosa-MG, v.35, n.1, p.77-84, 2011 
ASSOCIATION OF OFFICIAL ANALYTICAL CHEMISTRY - AOAC. Official Methods of Analysis. Washington: 1995.

BONNER, F. T. Storage of seeds: potential and limitations for germoplasm conservation. Forest Ecology and Management, v.35, n.1-2, p.35-43, 1990.

BRADFORD, K. J. Water relations in seed germination. In: KIGEL, J.; GALILI, G. (Eds.). Seed development and germination. New York: Marcel Dekker, 1995. p.351-396.

BROOKER, D. B.; BAKKER-ARKEMA, F. W.; HALL, C. W. Grain equilibrium moisture content. In: Drying and storage of grains and oilseeds. New York: 1992. p.67-86.

CHAVES, M. M. F.; USBERTI, R. Controlled seed deterioration in Dalbergia nigra and Dimorphandra mollis, endangered Brazilian forest species. Seed Science and Technology, v.32, n.3, p.883-893, 2004.

DICKIE, J. B. et al. Temperature and seed storage longevity. Annals of Botany, v.65, n.2, p.197-204. 1990.

ELLIS, R. H. The meaning of viability. In: DICKIE, J. B.; LININGTON, S. H.; WILLIAMS, J. T. (Eds.). Seed management techniques for genebanks: a report of a workshop. Rome: International Board for Plant Genetic Resources, 1984. 294p.

ELLIS, R. H.; ROBERTS, E. H. Improved equations for the prediction of seed longevity. Annals of Botany, v.45, n.1, p.13-30, 1980.

ELLIS, R. H.; HONG, T. D.; ROBERTS, E. H. A comparison of the low-moisture-content limit to the logarithmic relation between seed moisture and longevity in twelve species. Annals of Botany, v.63, n.6, p.601-611, 1989.

GENTIL, D. F. O.; FERREIRA, S. A. N. Preparação das subamostras, temperatura e período de secagem na determinação do grau de umidade de sementes de Camu-Camu (Myrciaria dubia (H.B.K.) Mc Vaugh). (Preparation of sample, temperature and drying periods in the determination of the moisture content of CamuCamu (Myrciaria dubia (H.B.K.) Mc Vaugh) seeds). Brazilian Seed Journal, v.24, n.2, p.62-69, 2002.
HARRINGTON, J. F. Practical instructions and advice on seed storage. Proceedings of the International Seed Testing Association, v.28, n.4, p.989-994, 1963.

HAY, F.R. et al. One-step analysis of seed storage data and the longevity of Arabidopsis thaliana seeds. Journal of Experimental Botany, v.54, n.384, p.993-1011, 2003.

INTERNATIONAL SEED TESTING ASSOCIATION - ISTA. International rules for seed testing. Zurich: 2006. 462p.

MEDEIROS, A. C. S. et al. The moisture relations of seed longevity in Astronium urundeuva (Fr. All.) Engl. Seed Science and Technology, v.26, n.2, p.289-298, 1998.

ROBERTS, E. H. Predicting the storage life of seeds. Seed Science and Technology, v.1, n.3, p.499-514, 1973.

SOUZA, G. M.; CARDOSO, V. J. M. Effects of different environmental stresses on seed germination. Seed Science and Technology, v.28, n.3, p.621-630, 2000.

TOMPSETT, P. B. The effect of temperature and moisture content on the longevity of seed of Ulmus carpinifolia and Terminalia brassii. Annals of Botany, v.57, n.6, p.875-83, 1986.

USBERTI, R.; GOMES, R. B. G. Seed viability constants for groundnut. Annals of Botany, v.82, n.5, p.691-694, 1998.

USBERTI, R.; ROBERTS, H. E.; ELLIS, H. R. Prediction of cottonseed longevity. Brazilian Journal of Agricultural Research, v.41, n.9, p.1435-1441, 2006.

VIEIRA, J. D.; DINIZ, A. S. Colheita, secagem e beneficiamento de sementes de Eucalyptus na Champion Papel e Celulose Ltda. (Eucalyptus harvesting, drying and seed processing at Champion Paper and Cellulose Co.) In: Manual Técnico de Sementes Florestais. (Technical Handbook of Forest Seeds). v.14, p.13-20, 1995. 